\title{
METODE ROLE PLAYING BERBANTU MEDIA AUDIO VISUAL PENDIDIKAN DALAM MENINGKATKAN BELAJAR IPS
}

\author{
Arsyad ${ }^{1)}$, Wahyu Bagja Sulfemi ${ }^{2}$ \\ ${ }^{1,2)}$ STKIP Muhammadiyah Bogor \\ Arsyad@gmail.com ${ }^{l)}$, wahyubagja@gmail.com ${ }^{2)}$
}

\begin{abstract}
Abstrak : Penelitian ini adalah Penelitian Tindakan Kelas (PTK) yang dilaksanakan pada peserta didik SD Negeri Beji 5 yang berjumlah 40, terdiri dari 20 orang perempuan dan 20 orang laki-laki. Penelitian ini bertujuan untuk meningkatkan hasil belajar IPS Kelas 3 SD Negeri Beji 5 dengan metode pembelajaran Role Playing dan media audio visual. Dari hasil pada pembelajaran prasiklus dengan KKM 75 di peroleh rerata kelas 58,25. Peserta didik yang tuntas hanya $7(17,5 \%)$ dan dapat menjawab 10 (25\%) sedangkan yang tidak menjawab ada 30 peserta didik atau $75 \%$. Pada siklus 1 hasil Rata-rata adalah 70,8. yang tuntas sebanyak 23 orang $(57,5 \%)$ dan hasil pengamatan hanya $25(62,5 \%)$ dapat menjawab. Pada siklus 2 nilai rata-rata kelas sebesar 81,88 . Peserta didik yang tuntas dalam pelajaran sebanyak 40 $(100 \%)$ dan sedangkan hasil pengamatan yang dapat menjawab $40(40 \%)$, sedangkan hasil pengamatan yang dapat menjawab dan tidak dapat menjawab diperoleh 40 orang peserta didik dapat menjawab atau $100 \%$. Dengan demikian pembelajaran menggunakan metode Role Playing dengan media audio visual dapat meningkatkan hasil belajar, keaktipan serta motivasi, materi yang disampaikan oleh guru dapat dimengerti, tanggung jawab peserta didik terhadap tugas cukup tinggi, dan membantu peserta didik untuk terlibat aktif di dalam kegiatan pembelajaran.
\end{abstract}

\section{Kata-kata kunci : Role Playing audio visual, Belajar dan IPS}

\section{PENDAHULUAN}

Upaya peningkatkan sumberdaya manusia yang berkualitas, bidang pendidikan memegang peranan penting karena pendidikan akan dapat mengembangkan kemampuan serta meningkatkan mutu kehidupan bangsa Indonesia. Disamping itu akan terwujud sumber daya manusia yang terampil, potensial dan berkualitas sebagai pelaksana pembangunan dalam mewujudkan tujuan Nasional.

Tujuan ini sejalan dengan tujuan dari mata pelajaran Ilmu Pengetahuan Sosial (IPS) dimana IPS bertujuan untuk membentuk warga negara yang baik, melatih peserta didik berkemampuan berpikir matang untuk menghadapi, dan memecahkan masalah sosial, dan agar peserta didik dapat mewarisi dan melanjutkan budaya bangsanya. Untuk mencapai tujuan ini maka hasil belajar peserta didik harus baik (Sulfemi, 2015)

Berdasarkan temuan penulis, sebagian besar peserta didik kurang aktif dan memahami materi IPS serta tidak dapat menyelesaikan jawaban dengan benar dikarnakan soalnya yang sulit. Apabilapeserta didik mengalami masalah tersebut dan nilai IPS selalu rendah dengan rata-rata kurang dari KKN, yaitu nilai ulangan harian rata-ratanya 45 dari 40 peserta didik, bahkan jauh dari harapan yang pada ketentuan KKM yaitu 75.Dari masalah tersebut di temukan faktor-faktor penyebab mengapa hasil ulangan harian peserta didik di bawah KKM, yaitu : 1) Metode yang di gunakan tidak menarik, yaitu metode ceramah, 2) Lingkungan yang kurang kondusif di karnakan dekat pembuangan sampah, dan 3) Kondisi jam belajar anak kelas III, yaitu jam 12.30 sampai dengan 16.30. Dari hasil tersebut peserta didik tidak mampu menerima informasi yang disampaikan sesuai dengan tujuan yang telah di tetapkan oleh guru dengan merujuk pada tidak tercapainya KKM Mata Pelajaran IPS. Rendahnya Hasil belajar IPS ini sesuai dengan penelitian dari Sulfemi dan Nurhasanah (2018)

Rendahnya hasil belajar tersebut banyak faktor terutama factor guru dan peserta didik Guru sebagai komponen penting dalam proses belajar mengajar mempunyai peran yang sangat strategis dalam usaha pembentukan sumber daya manusia berkualitas (Sulfemi, 2017). Dalam hal ini guru melaksanakan tugasnya baik sebagai perencana pengajaran, sebagai pelaksana, maupun sebagai evaluator pengajaran. Bahkan guru diharapkan memodifikasi rancangan dan pelaksanaan pengajaran, berperan aktif serta menempatkan kedudukannya sebagai tenaga profesional, sesuai dengan tuntutan masyarakat yang semakin berkembang untuk meningkatkan hasil belajar peserta didik sesuai dengan harapan Sulfemi, 2018) dan (Arsyad dan Salahudin. (2018).

Media pembelajaran yang digunakan oleh guru dalam proses pembelajaran memiliki andil untuk menjelaskan hal-hal yang abstrak dan menunjukan hal-hal yang tersembunyi. Ketidakjelasan atau kerumitan materi pembelajaran dapat 
dibantu dengan menghadirkan media sebagai perantara. Bahkan dalam hal-hal tertentu media dapat mewakili kekurangan guru dalam mengkomunikasikan materi pelajaran. Akan Tetapi, perlu diingat bahwa peranan media tidak akan terlihat apabila penggunaanya tidak sejalan dengan esensi tujuan pengajaran yang telah dirumuskan. Untuk itu tujuan pengajaran harus dijadikan sebagai pangkal acuan untuk menggunakan media. (Sulfemi, 2018)

Berdasarkan faktor-faktor masalah di atas, penulis mengadakan perbaikan pembelajaran khususnya pelajaran IPS melalui penelitian tindakan kelas. Penelitian yang peneliti lakukan menerapkan metode role playing. Role playing adalah suatu metode bermain peran kepada peserta didik agar bisa memahami situasi sejarah sumpah pemuda pada saat itu, peserta didik juga dapat melatih bersosialisasi dengan mudah, Zainal Aqib dan Ali Murtadlo (2016: 186) dan diharapkan juga nilai peserta didik mencapai KKM.

Berdasarkan latar belakang masalah maka rumusan yang dapat saya sampaikan adalah bagaimana meningkatkan hasil belajar siswa dengan metode role palying melalui media audio visual pelajaran Ilmu Pendidikan Sosial (IPS) kelas III di SDN Beji 5 Depok?. Berdasarkan hasil analisis masalah di atas, maka dapat diperinci sebagai berikut : 1) Bagaimana meningkatkan hasil belajar peserta didik dengan metode Role Playing pelajaran IPS Kelas III di SDN Beji 5, dan 2) Bagaimana meningkatkan hasil belajar peserta didik memalui media Audio visual pelajaran IPS Kelas III di SDN Beji 5.

\section{METODE}

Metode penelitian yang diterapkan adalah classroom action research atau yang dikenal dengan Penelitian Tindakan Kelas (PTK). Penelitian tindakan (action research) adalah suatu penelitian yang dikembangkan bersama-sama antara peneliti dan decision maker tentang variabel-variabel yang dapat dimanipulasikan dan dapat segera digunakan untuk menentukan kebijakan dan pembangunan.

Menurut Arikunto (2008), "penelitian tindakan kelas merupakan suatu pencermatan terhadap kegiatan belajar berupa sebuah tindakan, yang sengaja dimunculkan dan terjadi dalam sebuah kelas secara bersama”. PTK ini dilakukan secara kolaboratif dan partisipatif. Kolaboratif artinya peneliti bekerja sama dengan guru kelas sedangkan partisipatif artinya peneliti dibantu partisipasi teman sejawat yang disebut observer (Asrori, 2009:6).

Subjek penelitian dalam PTK ini adalah peserta didik kelas III SD Negeri Beji 5 sebanyak 40 orang terdiri dari Laki-laki 20 orang dan Perempuan 20 orang Mata Pelajaran Ilmu Pengetahuan Sosial yang dilaksanakan Penelitian Tindakan Kelas dilaksanakan mulai tanggal 06 Agustus 2017 sampai dengan 16 Agustus 2017.

Instrumen yang dibutuhkan dalam penelitian ini adalah: 1) Tes. Penelitian ini menggunakan instrumen tes kuis dan tes hasil belajar. Tes kuis diberikan di setiap akhir pembelajaran, berfungsi sebagai pengukur keberhasilan penyampaian materi pada pertemuan tersebut. Sedangkan tes hasil belajar diberikan pada akhir siklus I dan siklus II, berfungsi untuk mengetahui kemampuan siswa dalam menyelesaikan soal matematika sekaligus mengetahui tingkat hasil belajar siswa.
2) Pedoman observasi. Lembar observasi digunakan untuk mengamati hal-hal yang terjadi selama proses pelaksanaan pembelajaran berlangsung. Komponen observasi terdiri dari lembar observasi untuk aktivitas guru, siswa, dan materi. 3) Catatan Lapangan, yaitu catatan tertulis mengenai apa yang didengar, dilihat, dialami, dan dipikirkan dalam rangka mengumpulkan data dan refleksi terhadap data dalam penelitian kualitatif (Yusnita dan Munzir, 2017 : 23-38). 4) Dokumentasi, instrumen ini digunakan sebagai penguat data yang diperoleh sekaligus sebagai gambaran nyata pelaksanaan penelitian. Dokumen ini berupa kumpulan foto aktivitas pembelajaran. (Daryanto, $2011: 6$ )

Untuk mengukur keberhasilan penelitian menggunakan keberhasilan indikator. Indikator keberhasilan penelitian : 1) Penelitian dikatakan berhasil dalam proses pembelajaran apabila aktivitas siswa membuat kesimpulan mencapai keberhasilan $\geq 80 \%$. 2) Penelitian dikatakan berhasil dalam proses pembelajaran apabila aktivitas siswa membuat kesimpulan mencapai keberhasilan $\geq 80 \%$. 3) Hasil belajar siswa dianggap tuntas apabila secara individu pada hasil evaluasi memeroleh nilai $\geq 75$. Sedangkan ketuntasan klasikal tercapai apabila seluruh siswa dalam kelas tersebut tuntas belajarnya sebanyak $\geq 80 \%$. (Yusnita dan Munzir, $2017: 23$ 38). 4)

Data yang dikumpulkan pada setiap kegiatan penelitian dari pelaksanaan siklus penelitian dianalsis secara deskriptif dengan menggunakan teknik persentase untuk melihat kecenderungan yang terjadi dalam kegiatan pembelajaran mata pelajaran IPS.

Untuk menilai ulangan atu tes formatif Peneliti melakukan penjumlahan nilai yang diperoleh siswa, yang selanjutnya dibagi dengan jumlah siswa yang ada di kelas tersebut sehingga diperoleh rata-rata tes formatif dapat dirumuskan $\bar{X}=\frac{\sum X}{\sum N}$, Rentang Data dengan rumus $\mathrm{R}=\mathrm{X}_{\mathrm{t}}-\mathrm{X}_{\mathrm{r}}$, Banyaknya Kelas (BK) dengan rumus $\mathrm{K}=1+3,3 \log \mathrm{n}$, Panjang Interval (P) dengan rumus $\mathrm{P}=\frac{\mathrm{R}}{\mathrm{BK}}$, Presentase frekuensi dengan rumus $\mathrm{P}=\frac{f}{N} \times 100 \%$

Kategori ketuntasan belajar berdasarkan petunjuk pelaksanaan belajar mengajar kurikulum 1994 (Sulfemi, 2018) yaitu seorang siswa telah tuntas belajar bila telah mencapai skor $65 \%$ atau nilai 75 , dan kelas disebut tuntas belajar bila di kelas tersebut terdapat $85 \%$ yang telah mencapai daya serap lebih dari sama dengan $65 \%$. Untuk menghitung persentase ketuntasan belajar digunakan rumus sebagai berikut:

$$
\mathrm{P}=\frac{\text { Speserta didik yang tuntas belajar }}{\text { Npeserta didik keseluru han }} \times 100 \%
$$

Hasil data yang dikumpulkan pada setiap kesgiatan penelitian dari pelaksanaan siklus penelitian dianalisis secara deskriptif dengan menggunakan teknik presentase untuk dapat melihat kecendrungan yang terjadi dalam kegiatan pembelajaran mata pelajaran IPS (Wardani $2014: 1.4$ ) dan (Sulfemi, 2016).

\section{HASIL DAN PEMBAHASAN}

Hasil penelitian pembelajaran pada penelitian diharapkan agar mendapat hasil yang memuaskan bagi peserta didik, pengajar, orang tua, dan bagi masyarakat, dan oleh sebab itu 
juga penelitian ini dapat berguna bagi kemajuan sekolah. Pada penelitian ini peneliti memeliki tahapan perbaikan yang terdapat 2 siklus di dalamnya dan di akhiri dengan hasil yang sangat memuaskan dari hasil penelitian perbaikan pembelajaran.

Pada kegiatan pembelajaran prasiklus pada tanggal Rabu, 02 Agustus 2017 dengan menggunakan metode ceramah dengan media papan tulis, buku IPS diperoleh skor peserta didik pada prasiklus yang hasilnya kurang memuaskan peneliti, di dalam kelas tersebut terdapat 20 peserta didik laki-laki dan 20 pesertadidik perempuan, seluruh peserta didik kelas 3 adalah 40 orang. yang tuntas $7(17,5 \%)$ dan tidak tuntas 33( 82,5\%). Dari hasil evaluasi yang di peroleh dari keseluruhan adalah 2330 dengan rincian nilai tertinggi 80, ada 7 peserta didik.

Dari data dieproleh interval kelas Suryanto (2016) sebagai berikut retang 50, banyaknya kelas interval 5,28 dibulatkan menjadi 6, panjang kelas interval 8,33dibulatkan menjadi 9. Berdasarkan Frekuensi Hasil Belajar IPS prasiklus dapat diketahui jumlah peserta didik yang berada di rentang nilai 30 - 38 ada 1 peserta didik, 39 - 47 ada 4 peserta didik, 48 - 56 ada 13 peserta didik, $57-65$ peserta didik, $66-74$ ada 3 peserta didik, dan $75-83$ ada 7 peserta didik.

Hasil dari Dari 40 peserta didik, hanya 10 peserta didik yang dapat menjawab yaitu $25 \%$, sedangkan yang tidak dapat menjawab 30 peserta didik yadtu $75 \%$. Dengan demikian hasil prasiklus peserta didik belum sepenuhnya mencapai KKM 75. Rendahnya Penelitian ini seperti penelitain Sulfemi dan Nurhasanah (2018)

Hasil kegiatan pembelajaran prasiklus yang tidak mencapai Ketuntasan Mininimun (KKM), maka peneliti melanjutkan ke perbaikan pembelajaran ke Siklus 1 pada tanggal Rabu, 09 Agustus 2017 dengan menggunakan meodel pembelajaran role playing dengan media papan tulis, buku IPS. Pada kegiatan siklus 1 dipeoleh nilai keseluruhan adalah 2832 dengan rata-rata kelas 70,8 dengan rincian nilai tertinggi 92 terendah 40, sekor siklus 1 yang tuntas $23(57 \%)$ dan tidak tuntas $17(42 \%)$.

Hasil perhitungan interval nilai hasil belajar IPS pada Siklus 1 diperoleh rentang 52, banyaknya kelas interval 5,76 dibulatkan menjadi 6 , dan panjang kelas interval (p) diperoleh 8,66 dibulatkan menjadi 9. Berdasarkan tersebut hasil evaluasi nilai IPS Siklus 1 di atas dapat diketahui jumlah peserta didik yang berada di rentang nilai 40 - 48 ada 3 peserta didik, 49 57 ada 3 peserta didik, 58 - 66 ada 6 peserta didik, $67-75$ ada 6 peserta didik, $76-84$ ada 19 peserta didik, dan $85-93$ ada 3 peserta didik.

Hasil pengamatan guru pada peserta didik yang bisa menjawab dan tidak bisa menjawab dari 40 peserta didik di siklus 1, hanya 27 peserta didik yang dapat menjawab yaitu $67,5 \%$, sedangkan yang tidak dapat menjawab 13 peserta didik yaitu $32,5 \%$.

Dari deskripsi di atas dapat di simpulkan bahwa hasil peserta didik mendapatkan skor di bawah KKM. Berdasarkan nilai rata-rata dapat di simpulkan bahwa peserta didik belum $100 \%$ mencapai KKM. Dengan demikian pada siklus 1 ini peneliti belum merasa ada kepuasan sehingga akan di lanjutkan pada siklus 2. Rendah hasil belajar ini seperti yang disampikan Sri Anita W. (2014: 5.24) bahwa role playing memiliki kelemahan.

Hasil kegiatan pembelajaran Siklus 1 yang tidak mencapai KKM, maka peneliti melanjutkan ke perbaikan pembelajaran ke Siklus 2, pada hari Rabu, 16 Agustus 2017 dengan menggunakan pembelajaran role playing dengan media papan tulis, buku IPS ditambah media audio visual. Pada kegiatan siklus 2 yang hasilnya memuaskan peneliti, Dari hasil evaluasi yang di peroleh dari keseluruhan adalah 3275 dengan rata-rata kelas 82 dengan rincian nilai tertinggi 95 dan nilai terendah 75 , dari nilai tertinggi dan terendah sudah memenuhi KKM, sehingga mengalami peningkatan.

Hasil perhitungan interval nilai hasil belajar IPS pada siklus 2 diperoleh rentang 20, banyaknya kelas interval 5,76 dibulatkan menjadi 6, dan panjang kelas interval (p) diperoleh 4. Berdasarkan Frekuensi Hasil Belajar IPS siklus 2 di atas maka dapat diketahui jumlah peserta didik yang berada di rentang nilai $75-78$ ada 18 peserta didik, $79-82$ ada 5 peserta didik, 83 - 86 ada 6 peserta didik, 87 - 90 ada 5 peserta didik, 91- 94 ada 0 peserta didik, dan 95 - 97 ada 6 peserta didik.

Hasil pengamatan guru pada peserta didik yang bisa menjawab dan tidak bisa menjawab dari 40 peserta didik di siklus 2 dapat menjawab dengan baik dan peserta didik sudah $100 \%$ dapat mencapai KKM.

Dari deskripsi di atas dapat di simpulkan bahwa hasil peserta didik mendapatkan skor sesuai KKM. Berdasarkan nilai rata-rata dapat di simpulkan bahwa peserta didik sudah $100 \%$ mencapai KKM.

Berikut rangkuman Hasil Belajar Peserta Didik dan Hasil pengamatan Belajar Peserta Didik setiap siklus yang disajikan dalam tebel dan grafik berikut ini

Tabel 1

Rangkuman Persentase Keberhasilan Hasil Belajar Peserta Didik

\begin{tabular}{|l|c|c|c|c|c|c|c|}
\hline \multirow{2}{*}{ No } & \multirow{2}{*}{ Kriteria } & \multicolumn{2}{|c|}{ Prasiklus } & \multicolumn{2}{c|}{ Siklus 1 } & \multicolumn{2}{c|}{ Siklus 2 } \\
\cline { 2 - 8 } & Jmlh & \% & Jmlh & \% & Jmlh & \% \\
\hline 1 & Tuntas & 7 & 17,5 & 23 & 57,5 & 40 & 100 \\
\hline 2 & $\begin{array}{l}\text { Belum } \\
\text { Tuntas }\end{array}$ & 33 & 82,5 & 17 & 42,5 & - & - \\
\hline 3 & Rerata & \multicolumn{2}{|c|}{58,25} & \multicolumn{2}{|c|}{70,77} & \multicolumn{2}{c|}{81,88} \\
\hline
\end{tabular}

Bila di gambarkan dalam bentuk grafika, sebagai berikut:

Grafik 1

Ketuntasan Belajar Peserta Didik Setiap Siklus

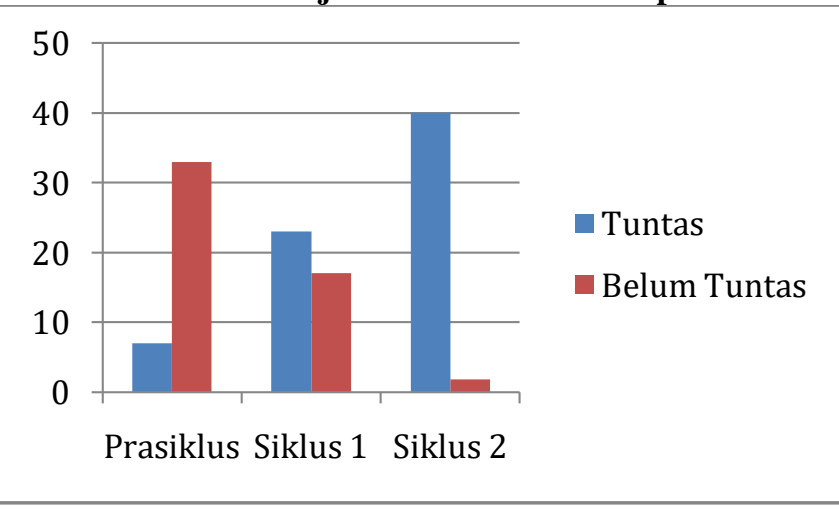


Tabel 2

Rangkuman Persentase Keberhasilan Hasil Pengamatan Belajar Peserta Didik

\begin{tabular}{|c|c|c|c|c|c|c|c|}
\hline \multirow{2}{*}{ No } & \multirow{2}{*}{ Kriteria } & \multicolumn{2}{|c|}{ Prasiklus } & \multicolumn{2}{c|}{ Siklus 1 } & \multicolumn{2}{c|}{ Siklus 2 } \\
\cline { 2 - 8 } & Jmlh & \% & Jmlh & $\%$ & Jmlh & $\%$ \\
\hline 1 & $\begin{array}{c}\text { Dapat } \\
\text { Menjawab }\end{array}$ & 10 & $25 \%$ & 27 & $67,5 \%$ & 40 & $100 \%$ \\
\hline 2 & $\begin{array}{c}\text { Tidak Dapat } \\
\text { Menjawab }\end{array}$ & 30 & $75 \%$ & 13 & $32,5 \%$ & - & - \\
\hline 3 & Jumlah & 40 & $100 \%$ & 40 & $100 \%$ & 40 & $100 \%$ \\
\hline
\end{tabular}

Sedangkan dari data pengamatan dapat di buat grafik sebagai berikut:

\section{Grafi 2}

Pengamatan GuruTerhadap Peserta Didik Yang Dapat Menjawab dan Tidak Dapat Menjawab

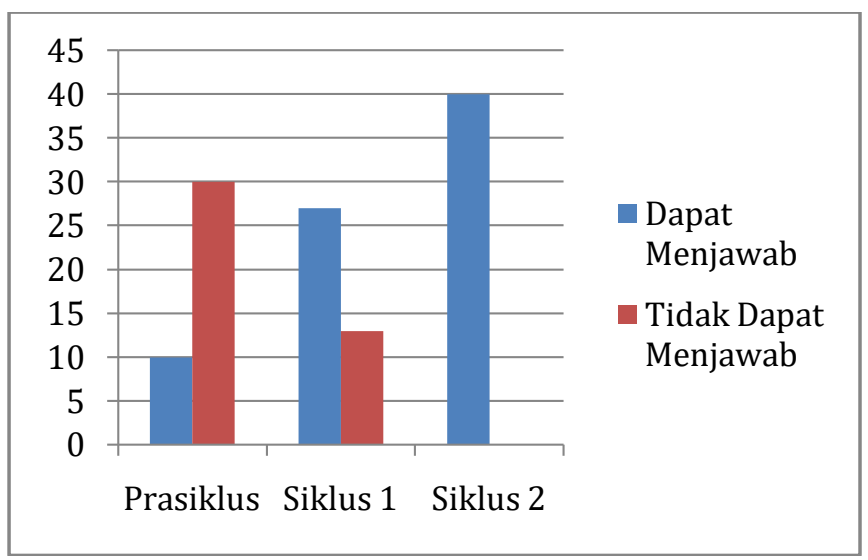

Berdasarkan tabel dan grafik diatas perbandingan perolehan hasil nilai rerata kelas dan ketuntasan belajar pada prasiklus, siklus I dan siklus II terus mengalami peningkatan. Demikian pula dengan pengamatan guru yang mengalami peningkatan. Hal ini menunjukan pemahaman peserta didik terhadap pembelajaran meningkat pula.

Hasil kegiatan pembelajaran Prasiklus yang merupakan kondisi awal hasil belajar peserta didik jauh dari nilai Kriteria Ketuntasan Mininimun KKM. Setelah pembelajaran prasiklus dilaksanakan, maka peneliti bersama guru mengadakan kolaborasi untuk membuat analisa, sintesa, interpretasi, atau penjelasan (eksplanasi) terhadap semua informasi yang diperoleh dalam proses pembelajaran berlangsung dengan teman sejawat, kemudian temuan tadi didiskusikan untuk mengetahui persentase pelaksanaan prasiklus dan ternyata hasil yang diperoleh belum memuaskan dan temuan yang diperoleh adalah rendahnya hasil belajar peserta didik pada mata pelajaran IPS. Dari hasil pengamatan, hal yang perlu disikapi guru sebagai peneliti, agar pada pembelajaran selanjutnya dapat berlangsung lebih baik dan peserta didik dapat menjawab pertanyaan secara aktif dan menjawab soalsoal evaluasi dengan benar, langkah-langkah yang dilakukan adalah sebagai berikut: 1) Guru sebaiknya menyampaikan materi memberi contoh yang konkret agar peserta didik lenih mudah memahami materi yang disampaikan, 2) Guru sebaiknya metode mengajar yang variatif dan menarik agar meningkatkan hasil belajar peserta didik, 3) Guru sebaiknya menggunakan media pembelajaran yang menarik dan tepat agar peserta didik dapat memahami penjelasan guru, dan 4) Guru sebaiknya memotivasi peserta didik agar peserta didik aktif dalam kegiatan pembelajaran. Rendahnya hasil belajar Rendahnya nilai ini sesuai dengan penelitian yang dilakukan oleh Darmawan, (2017: 1-13) dan Hal ini sesuai yang disampaikan oleh Simbolon, dan Sahyar (2015; 299-315) bahwa model konvensional sulit menaikan nilai peserta didik .

Kegiatan pembelajaran Siklus 1 yang merupakan perbaikan pembelajaran menggunakan metode role playing dengan media papan tulis, buku IPS kalas 2 SD, dan LKS. Hasil evaluasi pelaksanaan pembelajaran Siklus I yang menunjukan peroleh yang kurang maksimal untuk itu maka dilakukan perbaikan pembelajaran berikutnya dengan melakukan tindakan dengan memotivasi peserta didik dengan kegiatan pembelajaran yang menarik dan menyenangkan dan memilih media atau alat peraga yang tepat dan dapat menarik perhatian peserta didik. Dalam mengatasi permasalahan tersebut, peneliti melakukan perbaikan pengajaran dengan menambahkan metode pembelajaran yang sesuai dengan kompetensi dasar dilanjutkan kesiklus berikutnya yaitu siklus 2 .

Dari hasil siklus 1 yang tidak menaikan nilai rata peserta ini maka peneliti meneruskan ke siklus 2.dengan melakukan tindakan seagai berikut : 1) menggunakan metode pembelajaran dan teknik pembelajaran yang bervariasi dan efektif yang sesuai secara maksimal sehingga peserta didik tidak mengaami kesulitan dan hasil belajar dapat diperoleh secara maksimal, 2) memberikan motivasi pada saat pembelajaran berlangsung sehingga peserta didik tertarik pada pelajaran IPS, 3) menggunakan media pembelajaran yang sesuai secara maksimal sehingga terciptanya suasana pembelajaran yang kondusif, dan menyenangkan bagi peserta didik, dan 4) Guru harus memberikan kesempatan kepada peserta didik untuk bertanya dan melibatkan peserta didik dalam materi ini.

Pada siklus dua penulis tetap menggunakan meteode metode sosiodrama atau role playing dimana menururt Fathurrohman (2015: 93), bermain peran (role playing) pada prinsipnya merupakan metode untuk menghadirkan peranperan yang ada dalam dunia nyata ke dalam suatu pertunjukkan peran di dalam kelas/pertemuan. Dapat penulis simpulkan bahwa, metode bermain peran (role playing) merupakan suatu pembelajaran bahasa yang berprinsip pada komunikasi yang dapat menimbulkan hubungan situasi sosial dalam kegiatan pembelajaran sehingga dapat meningkatkan keaktifan siswa dalam penggunaan bahasa secara lisan yang mengandung arti atau makna. Selain itu penulis mengunakan media audio visual

Pada siklus 2 yang hasilnya memuaskan peneliti, hasil ini sesuai dengan keunggulan metode pembelajaran bermain peran (role playing) dan media pendidikan audio visual seperti yang disampaikan oleh Azhar Arsad, M.A. (2014) dan Wahidmurni, Alifin Mustikawan, dan Ali Ridho. (2010) yaitu: 1) Dapat berkesan dengan kuat dan tahan lama dalam 
ingatan siswa, 2) Meningkatkan motivasi dan semangat dalam diri siswa serta menumbuhkan rasa kebersamaan 3) Menjadikan kelas lebih dinamis dan penuh antusias 4) Siswa belajar secara aktif dengan memerankan sesuatu yang akan dibahas dalam proses belajar.

Dengan demikian metode role playing atau bermain peran dan penggunaan media audio visual dapat meningkatkan hasil belajar minat, perhatian, dan motivasi peserta didik dalam bersimulasi, peserta didik juga dapat memahami lebih dalam kejadian pada waktu terebut, serta dapat meningkatkan kemampuan berkomunikasi dan berperan. Demikoan pula audio visual sebagai alat bantu mengajar pengganti tugas dan peran guru sebagai penyampai materi yang menarik dan penyajiannya semakin lengkap, dan dapat meningkatkan kualitas hasil belajar peserta didik dalam nilai IPS.

\section{KESIMPULAN}

Didasari dari hasil penelitian perbaikan yang telah di laksanakan mulai dari prasiklus sampai dengan siklus 2 pada IPS maka, penulis menarik kesimpulan, sebagai berikut : 1) Pada pembeajaran prasiklus dengan KKM 75 diperoleh rerata kelas 58,25. Peserta didik yang tuntas dalam belajar hanya berjumlah $7(17,5 \%)$ dan dapat menjawab $10(25 \%)$ peserta didik. Pada siklus 1 hasil rata-rata adalah 70,78. yang tuntas sebanyak $23(57,5 \%)$ peserta didik dan yang dapat menjawab $27(67,5 \%)$. Pada siklus 2 niai rata-rata kelas sebesar 81,88. Peserta didik yang tuntas dalam pelajaran sebanyak $40(100 \%)$ dan sedangkan hasil pengamatan yang dapat menjawab 40 (40\%) pertanyaan guru. 2) Motode bermain peran (Role Playing) Dapat meningkatkan hasil belajar siswa sampai $57,5 \%$ pada siklus 1. Guru dapat memahami karakteristik peserta didik dali pola belajar yang aktif dan kreatif, dan 3) Dengan media Audio visual yang di gunakan guru untuk menunjang pelajaran dapat meningkatkan nilai peserta didik hingga mampu mencapai KKM, dan guru dapat mengembangkan metode-metode baru sehingga peserta didik tidak mengalami kejenuhan.

Berdasarkan kesimpulan di atas ada beberapa hal yang sebaiknya dilakukan oleh guru dalam rangka meningkatkan prestasi belajar peserta didik antara lain : 1) Dalam upaya meningkatkan kualitas pembelajaran terutama keaktifan peserta didik dalam proses pembelajaran, guru hendaknya melakukan hal-hal yang dapat membantu terwujudnya upaya tersebut. 2) Guru membiasakan menganalisis hasil belajar peserta didik secara terus menerus, berkala, terprogram, dan berkesinambangungan, 3) Perbaikan pembelajaran melalui penelitian tindakan kelas memberi kontribusi dan manfaat bagi perbaikan proses pembelajaran, dan 4) Kepala sekolah hendaknya mampu menjadi motivator guru untuk menerapkan berbagai model dan media pembelajaran sehingga guru secara terus-menerus melakukan pembaharuan dalam dunia pendidikan. Selain itu, kepala sekolah juga hendaknya menjadi fasilitator, sehingga pembaharuan yang dilakukan guru dalam pembelajaran dapat terealisasi dengan optimal.

\section{DAFTAR PUSTAKA}

Asrori, Muhammad. (2009). Penelitian Tindakan Kelas. Bandung : CV Wacana Prima.

Arsyad, Azahra, (2014) Media Pembelajaran. Jakarta : Rajawali Pers

Aqib, Zainal dan Ali Murtadlo, (2016) Kumpulan Metode Pembelajaran Kreatif dan Inovatif. Bandung : Sarana Tutorial Nurani Sejahtera.

Arsyad., dan Sulfemi, Wahyu Bagja (2014). Minat Siswa Tentang Keadministrasian dengan Hasil Belajar Administrasi Perkantoran. Edutecno. 9 (2), 40-50

Arsyad, dan Salahudin. (2018). Hubungan Kemampuan Membaca Al Qur'an dan Minat Belajar Siswa Dengan Hasil Belajar Pendidikan Agama Islam (PAI). EDUKASI: Jurnal Penelitian Pendidikan Agama dan Keagamaan, 16(2), 166-178.

Anitah W, Sri dkk, (2014). Strategi Pembelajaran di SD.Tangerang Selatan: Universitas Terbuka

Daryanto, (2011). Penelitian Tindakan Kelas dan Penelitian Tindakan Sekolah Beserta contoh-contohnya, Yogyakarta: Gava Media

Djamarah, Syaiful Bahri \& Aswan Zain. (2010). Strategi Belajar-Mengajar (revisi). Jakarta: Rineka Cipta

Hamzah B. Uno. (2007). Model Pembelajaran Menciptakan Proses Belajar Mengajar yang Kreatif dan Efektif. Bandung : Bumi Aksaara

Karsiwan, Wawan dan Sulfemi, Wahyu Bagja (2016). Hubungan Penerimaan Diri Dengan Kinerja Guru SD Di Kecamatan Pamijahan Kabupaten Bogor Edutecno. 15. (1). 1-10.

Hernawan, Asep Herry, Novi Resmini, dan Andaani. (2016). Pembelajaran Terpadu di SD. Tanggerang Selatan: Universitas Terbuka.

Hamalik, Umar. (2002). Perencanaan Pengajaran Berdasarkan Pendekatan Sistem. Jakarta: PT. Bumi Aksara

Suryanto, Adi (2014). Evaluasi Pembelajaran di SD. Jakarta : Universitas Terbuka

Sulfemi, Wahyu Bagja. (2015). Pengaruh Metode Pembelajaran Kontekstual dan Penggunaan Media Video Pendidikan Terhadap Hasil Belajar IPS. Edutecno. 13 (2), 1-10.

Sulfemi, Wahyu Bagja. (2016). Hubungan atara Persepsi Guru pada Kepemimpian Kepala Sekolah dan Motivasi Guru dengan Kinerja guru dalam Proses Pembelajaran di SMA Negeri 1 Ciomas. Fascho : Kajian Pendidikan dan Sosial Kemasyarakatan,5 (1), 36-55

Sulfemi, Wahyu Bagja dan Abdul Qodir. (2017). Hubungan Kurikulum 2013 Dengan Motivasi Belajar Peserta Didik Di SMK Pelita Ciampea. Edutecno 17 (2), 1 8

Sulfemi, Wahyu Bagja. (2017). Analisis Pengaruh Motivasi dan Disiplin Terhadap Kinerja Guru (Studi Kasus Di SMA Negeri 1 Pamijahan Kabupaten Kabupaten Bogor). Prosiding Seminar Nasonal STKIP Muhammadiyah Bogor, 1 (1), 342-357 
Sulfemi, Wahyu Bagja. (2018). Pengaruh Kemampuan Pedagogik Guru dengan Hasil Belajar IPS. Edutecno 17 (1), 1-10

Sulfemi, Wahyu Bagja dan Nurhasanah. (2018). Penggunaan Metode Demontrasi dan Media Audio Visual Dalam Meningkatkan Hasil Belajar Peserta Didik Mata Pelajaran IPS. Jurnal Pendas Mahakam. 3 (2). 151-158

Sulfemi, Wahyu Bagja. (2018). Manajemen Kurikulum di Sekolah. Bogor : Visi Nusantara Maju.

Yusnita dan Munzir. (2017). Peningkatkan Hasil Belajar Pelajaran IPS Dengan Contextual Teaching Learning Melalui Media Gambar Siswa Sekolah Dasar. Faktor Jurnal Ilmiah Kependidikan. 4 (1). 23-38.

Uno, B. Hamzah, (2007). Model Pembelajaran: Menciptakan Proses Belajar Mengajar yang Kreatif dan Efektif. Jakarta: Bumi Aksara.

Winataputra, Udin S. (2014). Pembelajaran PKn di SD. Tanggerang Selatan: Universitas Terbuka.

Wahidmurni, Alifin Mustikawan, dan Ali Ridho. (2010). Evaluasi Pembelajaran: Kompetensi dan Praktik. Yogyakarta : Nuha Letera

Wardhani, IGAK. (2016). Penelitian Tindakan Kelas, Tangerang Selatan : Universitas Terbuka.

Widaryanto dan Sulfemi, Wahyu Bagja (2016). Korelasi Penguasaan TIK Guru dengan Kemampuan TIK Siswa. Edutecno. 14 (1). 1-10 